\title{
SOME TIPULIDAE FROM TIBET AND UPPER BURMA IN THE BRITISH MUSEUM (NATURAL HISTORY) (DIPTERA)
}

\author{
By CHARLES P. ALEXANDER
}

\section{SYNOPSIS}

The present report is based chiefly on collections of Tipulidae made by Frank Kingdon-Ward and Ronald J. H. Kaulback in Northeastern India, Burma and Southeastern Tibet between I93I and 1936. A few further species from Tibet and Pakistan are included. Fifteen species are defined as new.

WHILE engaged in general and botanical explorations in northeastern India, Burma and southeastern Tibet, the late Frank Kingdon-Ward and Ronald J. H. Kaulback collected and sent to the British Museum (Natural History) numerous specimens of insects, including various species of Tipulidae. The late Fred. W. Edwards, outstanding authority on this family of flies, died in November I940 before he was able to identify these materials and later the collection was submitted to me for study. A considerable part of the series had been determined and the specimens returned but there remained a relatively small number of species that now have been identified and are discussed at this time. All holotype specimens and named representatives of other species have been returned for preservation in the British Museum. I am greatly indebted to the Museum authorities for the opportunity of studying these specimens from an unusually desirable part of southeastern Asia.

Kingdon-Ward, accompanied by Lord Cranbrook, collected in Upper Burma, and particularly in the Adung Valley, throughout I93I, and published a detailed account of the expedition (Ward, I937, in list of References). In I933, he explored southeastern Tibet, in company with Ronald Kaulback (Ward, I934). Between April I935 and December I936, Kaulback, accompanied by John Hanbury-Tracy, revisited southeastern Tibet while endeavouring to trace the source of the Salween River and in both I935 and I936 collected various insect specimens (Kaulback, I939). The accompanying list of references cites works and papers that concern these three expeditions and previously published articles on the Tipulidae. The volumes by Ward and Kaulback contain a wealth of information concerning this region and may be consulted by interested parties.

\section{TIPULINAE}

\section{Ctenacroscelis luteistigmatus $\mathrm{sp} . \mathrm{n}$.}

Belongs to the brobdignagius group; mesonotal praescutum light brown, with two intermediate brown stripes that are separated by a broader yellowish grey central vitta ; pleura obscure yellow with a narrow pale brown dorsal stripe; femora yellow, tips narrowly and 
inconspicuously darkened; claws with a single rounded tubercle; wings weakly darkened, restrictedly patterned with darker brown, stigma conspicuously light yellow; abdominal tergites light brown, sternites yellow ; male hypopygium with outer dististyle triangular, strongly narrowed to the subacute tip ; inner dististyle strongly expanded at basal third, apex bidentate ; eighth sternite with the posterior border gently convex, with long brownish yellow setae that do not form brushes.

Male. Length, about $28 \mathrm{~mm}$.; wing, $30 \mathrm{~mm}$.; antenna about $3.3 \mathrm{~mm}$.

Frontal prolongation of head yellow above, weakly infuscated on sides of lower half, nasus elongate; palpi light brown, incisures pale, tip of terminal segment blackened. Antennae with scape brown, paler beneath ; remainder of organ light brown, the outer two or three segments dark brown; lower face of segments slightly produced, verticils short. Head brown, orbits narrowly pale; small pale spots adjoining eye behind the rounded vertical tubercle.

Pronotal scutum light brown, slightly darker in front, sides of scutellum yellowed. Mesonotal praescutum with ground light brown; two intermediate rich brown stripes separated by a broader yellowish grey central vitta, sublateral stripes more solidly brownish grey, lateral stripes yellowish brown; posterior sclerites of notum chiefly light brown ; central region of scutum with the posterior and lateral borders of mediotergite more yellowed. Pleura obscure yellow, vaguely and narrowly lined dorsally with pale brown on extreme margin of mesepisternum. Halteres with stem brown, knob slightly darker, base of stem restrictedly yellowed. Legs with coxae yellow, fore pair weakly darkened in front; trochanters yellow ; femora yellow, tips narrowly and inconspicuously darkened, tibiae and tarsi light brown ; last tarsal segment with a conspicuous epicondyle ; claw with a single rounded tubercle. Wings weakly darkened, costal border slightly more so ; narrow darker brown seams at $m-c u$ and outer end of cell Ist $M_{2}$; stigma conspicuously light yellow ; veins light brown. Veins behind $C$ unusually glabrous. Venation : Petiole of cell $M_{1}$ a little longer than $m ; m-c u$ at near twothirds $M_{3+4}$.

Abdominal tergites light brown, sternites yellow; eighth sternite light brown, the base and apex more yellowed. Male hypopygium (Text-fig. I) with the tergite, $t$, only slightly narrowed outwardly, posterior border with a V-shaped notch, lobes relatively narrow, tips obtuse ; midline narrowly glabrous, lobes with abundant yellow setae, the outer ones elongate. Outer dististyle, $d$, triangular, strongly narrowed to the subacute tip, the length about one-third greater than the width. Inner dististyle at near basal third strongly expanded, especially beneath, narrowed at midlength, the elongate outer end with relatively few setae, apex bidentate. Eighth sternite, $8 s$, with posterior border gently convex, with long brownish yellow setae, longer on the midregion but not forming brushes.

Holotype, ô, Burma : Hkamti Plain, I,500 ft., I5.x.I933 (R. J. H. Kaulback).

Ctenacroscelis luteistigmatus is readily told from other members of the brobdignagius group by the yellowed wing stigma and the structure of the male hypopygium, particularly both dististyles and the eighth sternite. C. albicostigma Alexander, of Malaya, has the wing pattern somewhat the same but differs conspicuously in body and leg coloration and in structure of the hypopygium.

\section{Tipula (Vestiplex) adungensis sp. n.}

General coloration of praescutum light grey with four narrow darker grey stripes that are conspicuously bordered by dark brown, posterior sclerites of notum with a darker brown central line; femora yellow, tips broadly brownish black; male hypopygium with dorsal tergal lobes obtusely rounded, with long delicate setae, ventral plate produced into a slender spine ; basistyle unarmed; appendage of ninth sternite a flattened yellow blade, its apex obliquely truncate ; inner dististyle with beak slender. 
SOME TIPULIDAE FROM TIBET AND UPPER BURMA

$32 \mathrm{I}$
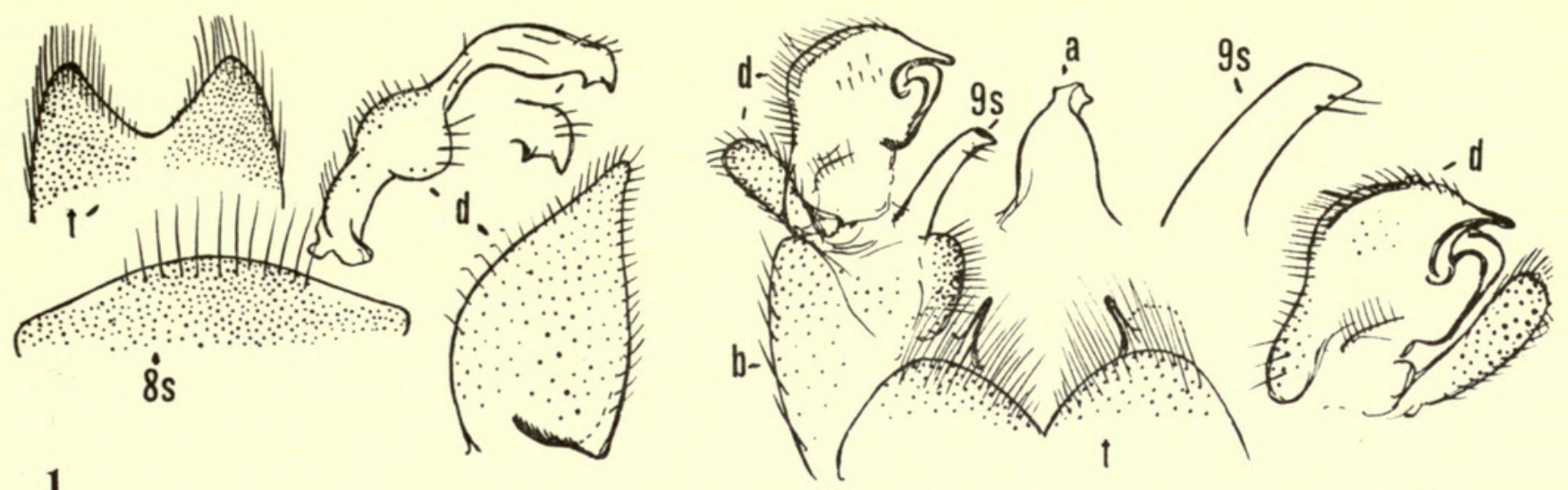

1

2
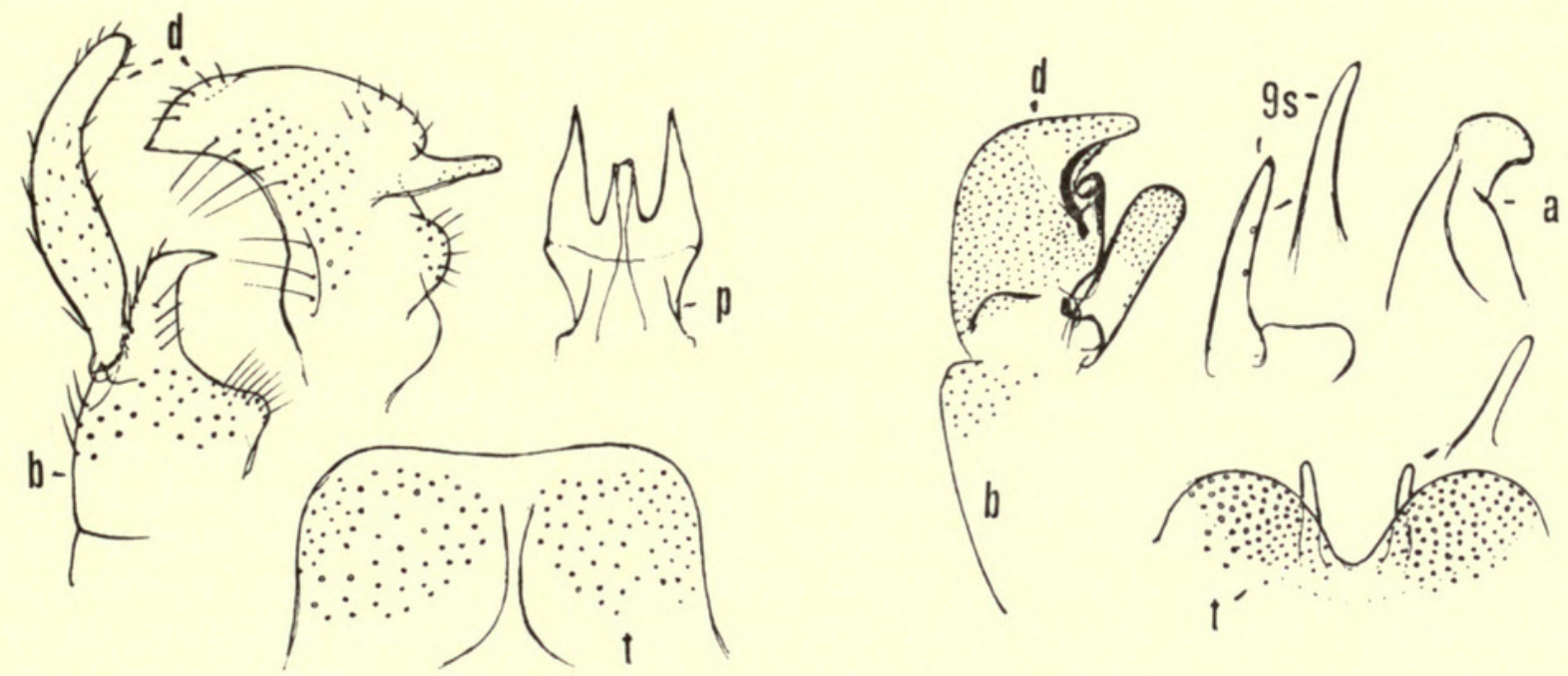

3

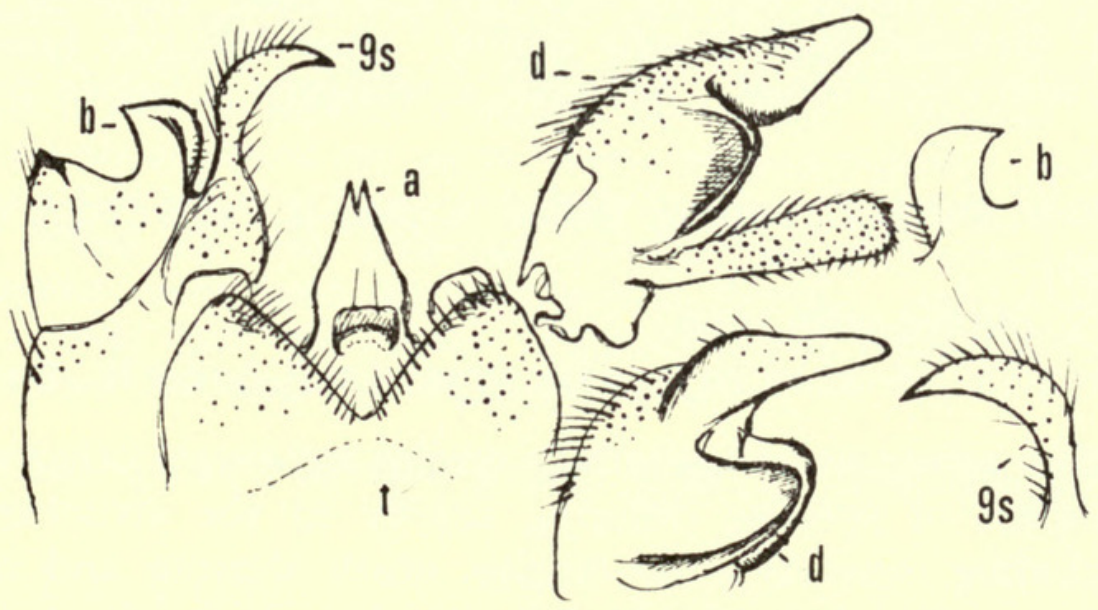

5

Figs. I-5. (TIPULINAE). I, Ctenacroscelis luteistigmatus sp. n. ; male hypopygium. 2, Tipula (Vestiplex) adungensis sp. n. ; male hypopogium. 3, Tipula (Vestiplex) alyxis sp. n. ; male hypopygium. 4, Tipula (Vestiplex) rongtoensis sp. n. ; male hypopygium. 5, Tipula (Vestiplex) freemanana sp. n. ; male hypopygium.

(Symbols : $a$, aedeagus ; $b$, basistyle ; $d$, dististyle ; $p$, phallosome ; $s$, sternite ; $t$, tergite.) 
Male. Length, about $13 \mathrm{~mm}$; wing, $16 \mathrm{~mm}$; antenna, about $4 \mathrm{~mm}$.

Female. Length, about $19-20 \mathrm{~mm}$.; wing, $19 \mathrm{~mm}$.

Frontal prolongation of head dark brown, grey pruinose, especially above; palpi black. Antennae with scape yellow beneath, darker pruinose and more corrugated above; pedicel testaceous yellow, flagellum black ; in male basal swellings poorly developed, segments slightly longer than the verticils. Head above grey, variegated by brown, including a central stripe on vertex, front more silvery ; vertical tubercle low.

Pronotal scutum buffy grey, anterior border dark brown, scutellum light grey. Mesonotal praescutum with ground light grey, disk with four narrow dark grey stripes that are conspicuously bordered by dark brown, including a common central vitta ; posterior sclerites of notum grey, scutal lobes patterned with brown, scutellum and mediotergite with an interrupted darker brown central line. Pleura light grey, dorsopleural region brown. Halteres with stem light brown, more yellowed at base, knob dark brown. Legs with coxae light grey ; trochanters yellow; femora yellow, tips broadly brownish black; tibiae brown, tips narrowly darker ; tarsi dark brown, claws small, with small basal tooth. Wings with ground light brown, variegated by slightly darker brown and cream-yellow areas ; cell $C$ pale brown, $S c$ clear yellow ; the darker brown areas include the stigma, anterior cord, origin of $R s$ and arculus ; yellowed areas beyond stigma, two in cell $M$, with others in $C u$ and the Anals; obliterative areas more whitened, the prestigmal one small, the larger one in base of cell Ist $M_{2}$ extended into base of cell $M_{3}$; veins light brown, more yellowed in the brightened parts. Venation : Rs about two and a half times $m-c u$; cell Ist $M_{2}$ elongate; petiole of cell $M_{1}$ subequal to or about twice the length of $m$.

Basal abdominal segments yellow, tergites with a narrow sublateral dark brown stripe, the extreme borders grey; basal sternites with darkened spots at base and at outer end, outer five segments, including hypopygium, blackened. In female, tergites conspicuously trivittate with brownish black, the broader central stripe continuous, outer sternites more pruinose. Male hypopygium (Text-fig. 2) with the dorsal tergal lobes, $t$, broadly obtuse, provided with long delicate setae; ventral arm on either side consisting of a flattened pale plate, its inner margin produced into a slender rod. Ninth sternite including a large darkened lobe with coarse erect setae ; appendage, $9 s$, a flattened yellow blade, gradually narrowed outwardly, apex obliquely truncate ; inner margin near tip with two long setae. Basistyle unarmed. Outer dististyle, $d$, short, darkened, apex broadly obtuse. Inner dististyle broad, beak slender, lower beak double, both blades obtuse. Aedeagus, $a$, triangular in outline, the narrowed apex decurved.

Holotype, ô, N.E. Burma : Adung Valley, I2,000 ft., Io.vi.I93I (Kingdon-Ward \& Lord Cranbrook).

Allotopotype, ㅇ, pinned with type.

Paratopotypes, 2 우우, 26-27.vi.I93I, with types ; I 우, 9,000 ft., 6.vi.I93I.

Tipula (Vestiplex) adungensis is generally similar to several other members of the himalayensis complex of species, differing chiefly in the structure of the male hypopygium, including especially the tergite, ninth sternite and inner dististyle. Other regional species that have the tergal setae long and delicate include $T$. (V.) rongtoensis sp. n., $T$. (V.) spathacea sp. n., and $T$. (V.) zayulensis sp. n.

\section{Tipula (Vestiplex) alyxis sp. n.}

Size relatively large (wing of male about I $7 \mathrm{~mm}$.) ; general coloration of head and thorax buffy, praescutum with four greyish brown stripes that are inconspicuously bordered by pale brown ; femora yellow, gradually darkening to the brownish black tips, in cases with a scarcely 
indicated brightening before apex ; wings light brown, with an inconspicuous pattern of light yellow areas ; abdomen of male yellow, outer five segments black, in female more uniformly yellow, tergites trivittate with brown; male hypopygium with posterior border of tergite transverse ; basistyle produced into a powerful blackened rod; phallosome including the short aedeagus and longer blackened spinoid apophyses.

Male. Length, about $\mathrm{I} 2-\mathrm{I} 3 \mathrm{~mm}$.; wing, I6-I $7 \mathrm{~mm}$.; antenna, about 5-5.5 mm.

Female. Length, about 21-22 mm.; wing, I7-18 mm.; antenna, about $3 \mathrm{~mm}$.

Frontal prolongation of head buffy yellow ; nasus elongate ; palpi light brown, terminal segment dark brown. Antennae of male relatively long; scape and pedicel light yellow, first flagellar segment brownish yellow, succeeding segments weakly bicolored, brown, the basal enlargement black, outer five or six segments more uniformly darkened; antennae of female shorter, the pattern generally the same. Head buffy, with a darkened central line on vertex.

Pronotum yellow. Mesonotal praescutum with the ground yellowed, with four greyish brown stripes that are narrowly and inconspicuously bordered by pale brown ; scutum yellow, lobes more reddish brown; scutellum and postnotum testaceous yellow. Pleura testaceous yellow, the ventral sternopleurite and meron more reddish yellow; dorsopleural membrane yellow. Halteres with stem yellow, knob dark brown. Legs with coxae and trochanters yellow ; femora yellow basally, gradually darkening outwardly, the tips narrowly brownish black ; in cases the femora slightly more yellowed before tips to form vague rings ; tibiae and tarsi brownish black to black; claws of male toothed. Wings light brown, inconspicuously variegated by light yellow areas, including a larger poststigmal band that extends backward to cell Ist $M_{2}$; other major yellow marks in cells $R, M, R_{1}$ and at near midlength of cells $C u$ and Ist $A$; more restricted similar areas in bases of cells $M_{3}$ and $M_{4}$, both ends of cell $2 n d A$, and less evidently in outer end of cell $R_{5}$; prearcular and costal regions more saturated yellow ; stigma oval, slightly darker than the ground; veins brown, more yellowed in the brightened areas. Macrotrichia lacking on all but outer ends of veins $M$ and $2 n d A$, Ist $A$ and basal section of $C u_{1}$ without trichia. Venation : $R_{1+2}$ preserved ; cell $M_{1}$ nearly twice its petiole.

Abdomen reddish yellow basally, the outer five segments in male black ; in female abdomen more uniformly yellow, tergites narrowly trivittate with brown. Ovipositor with lower margins of cerci conspicuously serrate, as common in the subgenus. Male hypopygium (Text-fig. 3) with tergite, $t$, large, approximately rectangular in outline, posterior border nearly truncate, with a weak middorsal furrow ; lobes on either side with abundant delicate setae, the outer ones smaller. Ninth sternite without a definite appendage. Basistyle, $b$, produced into a powerful rod, outwardly narrowed and curved into a blackened point ; surface with numerous setae, those of outer face longer. Outer dististyle, $d$, a flattened black blade or rod, gradually narrowed to the obtuse tip, with numerous inconspicuous pale setae. Inner dististyle as figured; beak slender, outer crest elevated, pointed behind; vestiture reduced in number and size of setae ; lower beak very obtuse. Phallosome, $p$, including the short aedeagus and longer blackened spines that represent the apophyses.

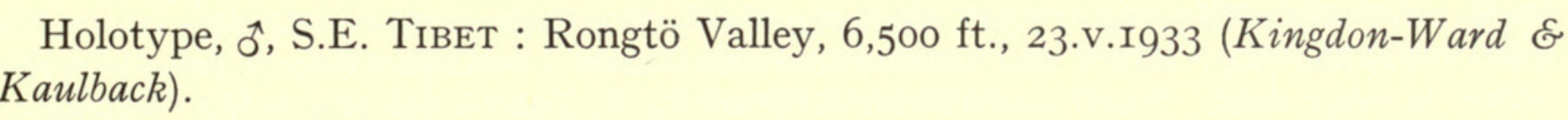

Allotopotype, ㅇ, 2I.v.I933.

Paratopotypes, I ô, 3 우, I9-23.v.I933.

Paratypes, I đే, Ata Kang La, Zayul, Io,000 ft., I6.vii.I933; I ㅇ, 8,000 ft., I6.vii.I933 ; I ठૈ, Rima Chu, Zayul, 6,000 ft., 20.iv.I933 (Kingdon-Ward \& Kaulback).

While generally similar to various other regional members of the himalayensis group, Tipula (Vestiplex) alyxis is quite distinct in the structure of the male hypopygium, particularly the tergite, inner dististyle and phallosome. In general appearance it somewhat suggests $T$. (V.) nigrotibialis Brunetti (lepcha Alexander). 


\section{Tipula (Vestiplex) avicularia Edwards}

Tipula avicularia Edwards, 1928, Ann. Mag. Nat. Hist. (10) 1 : 689-69o, fig. 7 (wing).

S.E. Tibet : Rongtö Valley, Rima Chu, Zayul, 6,000 ft., 20.iv.I933 (KingdonWard \& Kaulback).

\section{Tipula (Vestiplex) distifurca Alexander}

Tipula (Vestiplex) distifurca Alexander, I942, Rec. Indian Mus. 44 : 44-46, figs.

S.E. Tiвeт : Rongtö Valley (on label written “ Rong Thod ”), 6,00o ft., 3-5.v.I933 (Kingdon-Ward \& Kaulback).

\section{Tipula (Vestiplex) freemanana sp. $\mathbf{n}$.}

Mesonotal praescutum with broad greyish white borders, disk with four dark brown stripes, interspaces obscured, posterior sclerites of notum whitish grey with a central brown line ; femora brownish yellow, tips rather broadly black, claws of male simple ; wings light brown, marbled with pale yellow and slightly darker brown areas ; first abdominal tergite dull yellowish brown, succeeding four segments reddish yellow, broadly trivittate with black, outer segments black; male hypopygium with arm of basistyle a broad cultrate black blade ; appendage of ninth sternite a flattened semicultrate blade, its tip acute, surface with unusually conspicuous yellow setae.

Male : Length, about $15.5 \mathrm{~mm}$. ; wing, $17 \mathrm{~mm}$.

Frontal prolongation of head, including nasus, light cinnamon brown ; palpi with first segment brown, remainder black. Antennal scape light brown, pedicel yellow, flagellum broken. Head above obscure yellow, with a narrow light brown central darkening ; beneath light grey, genae infuscated.

Pronotal scutum brown. Mesonotal praescutum broadly greyish white on sides, disk with four dark brown stripes, the median interspace obscure brownish yellow, lateral interspaces dark grey ; scutum whitish grey, each lobe with two virtually confluent dark brown areas ; scutellum and mediotergite whitish grey with a central brown line, slightly darker on mediotergite ; katapleurotergite pale brown. Pleura grey, vaguely patterned with brown on sternopleurite and dorsal anepisternum ; dorsopleural membrane light brown. Halteres with stem brownish yellow, knob brownish black. Legs with coxae grey ; trochanters testaceous yellow ; femora brownish yellow, tips rather broadly black; tibiae and tarsi yellowish brown to light brown; claws of male small, simple. Wings light brown, variegated by large pale yellow areas, chiefly before the cord ; stigma medium brown, with a large darkened extension over the anterior cord; beyond stigma a major yellow area extending through cell $R_{5}$; whitened obliterative area before stigma small, the second area across base of cell Ist $M_{2}$ larger, extending into cells $R$ and $M_{3}$; cells $C$ and $S c$ light brownish yellow ; veins pale brown, more brownish yellow in costal field. Small macrotrichia on veins $R_{3}, R_{4+5}$ and outer end of $M_{1}$. Venation : $R s$ long, a little less than twice $m-c u$; petiole of cell $M_{1}$ subequal to $m$.

First abdominal tergite dull yellowish brown, succeeding four segments reddish yellow, broadly trivittate with black; sternites darker brown; outer segments uniformly black. Male hypopygium (Text-fig. 5) with dorsal tergal plate, $t$, large, posterior border with a deep V-shaped emargination ; lobes obtuse, bordered on inner margins with black setae of moderate length; ventral tergal armature ill-delimited, appearing as smooth plates, on microscope slide lying above base of ninth sternite. Ninth sternite with base darkened, with long yellow setae ; appendage, $9 s$, a flattened semicultrate blade, widened on outer half, narrowed to the acute tip, surface with unusually conspicuous yellow setae. Basistyle, $b$, small, outer margin blackened but scarcely produced, the ventromesal arm a broad cultrate black blade that is connected with the appendage of the ninth sternite. Outer dististyle a dusky club, gradually 
narrowed outwardly, apex broadly obtuse. Inner dististyle, $d$, with apex of beak obtuse ; lower beak and plates appearing as blackened obtuse lobes. Aedeagus, $a$, broad at base, narrowed to the slightly bifid apex.

Holotype, ô, N.E. Burma : Adung Valley, I2,00o ft., 8.viii.I93I (Kingdon-Ward \& Lord Cranbrook).

I take unusual pleasure in dedicating this fly to Dr. Paul Freeman, authority on the Orthorrhaphous Diptera, including the British Tipulidae. Tipula (Vestiplex) freemanana is generally similar to species such as $T$. (V.) avicularia Edwards, being best distinguished by the structure of the male hypopygium, particularly the tergite, ninth sternite and basistyle. The simple claws of the male are noteworthy.

\section{Tipula (Vestiplex) himalayensis Brunetti}

Tipula himalayensis Brunetti, I9II, Rec. Indian Mus. 6 : 252.

Tipula (Vestiplex) subreposita Alexander, I942, Rec. Indian Mus. 44 : 39-4I, fig. 5 ( ${ }^{\star}$ hypopygium).

S.E. Tibet : Rongtö Valley, Zayul, 3,000 ft., 28.iii.I933 ; 6,ooo ft., 6-I2.v.I933 ; Chu Valley, Ata Kang, 7,500-8,000 ft., 27-29.v.I933 (Kingdon-Ward \& Kaulback).

\section{Tipula (Vestiplex) rongtoensis $\mathrm{sp} . \mathrm{n}$.}

Size large (wing of male $20 \mathrm{~mm}$.) ; antennae relatively long ; mesonotum yellowish white, praescutum with four olive stripes that are narrowly bordered by light brown, scutellum and mediotergite with a darkened central line ; legs brownish black, claws of male small, simple ; wings light brown, patterned with darker brown and whitened areas ; macrotrichia of veins small ; abdomen buffy yellow, tergites trivittate with dark brown, outer segments blackened, eighth sternite dark, with two yellow marginal spots; male hypopygium with tergal lobes broadly rounded, thickened, with very abundant setae, on ventral surface of each lobe with a slender glabrous rod; appendage of ninth sternite a sclerotized rod with sparse setae ; outer dististyle with tip broadly obtuse ; inner dististyle with both the beak and lower beak well developed, the latter more sclerotized.

Male. Length, about $19 \mathrm{~mm}$.; wing, $20 \mathrm{~mm}$.; antenna, about $7 \mathrm{~mm}$.

Frontal prolongation of head long, subequal to the remainder, greyish yellow above, including the conspicuous nasus, lower half abruptly dark brown; palpi with first segment brown, remainder black, tips of second and third segments paler. Antennae long ; scape and pedicel yellow, first flagellar segment brown, remainder black; flagellar segments beyond the first with basal enlargement moderately developed, verticils shorter than the segments. Head pale olive yellow, more whitened near the antennal bases; a vague narrow brown central vitta from the low vertical tubercle onto the posterior vertex.

Pronotum olive yellow, vaguely patterned with darker. Mesonotal praescutum yellowish white with four olive stripes that are narrowly bordered by light brown, including the narrow median dividing vitta, vestiture pale ; scutum yellowed medially, lobes olive, ringed with pale brown ; scutellum darker yellow, mediotergite yellowish white, each with a nearly continuous brown central vitta. Pleura and pleurotergite pale olive yellow, variegated with darker on ventral sternopleurite ; katapleurotergite silvery white; dorsopleural membrane very light brown. Halteres with stem obscure yellow, knob dark brown. Legs with coxae olive yellow ; trochanters yellow ; femora light brown, tips narrowly brownish black, bases narrowly more yellowed ; tibiae and tarsi dark brown ; claws small, simple. Wings with ground light brown, prearcular and costal fields more yellowed ; a slightly darker brown pattern including stigma, origin of $R s$ and anterior cord ; whitened areas include a narrow poststigmal band from costa 
into base of cell $R_{5}$; obliterative areas in cell Ist $M_{2}$ and adjoining bases of $M_{3}$ and $M_{4}$; other pale areas before and beyond origin of $R s$, near base and again near outer end of cell $M$, and more vaguely in the cubital and anal cells; veins brown, more brownish yellow in the brightened fields. Macrotrichia of veins small, including certain longitudinal veins beyond cord, as the Medial veins except at their outer ends ; trichia on distal section of $C u_{1}$ and outer two-thirds of $2 n d A$, lacking on $R s, R_{2+3}, m$, and ist $A$. Venation : Rs long, about two and a half times $R_{2+3}$; cell $M_{1}$ about three times its petiole, the latter subequal to $m ; m-c u$ shortly beyond base of $M_{4}$.

Abdomen with basal segment buffy yellow, succeeding segments deeper yellow, tergites narrowly darkened sublaterally, the areas becoming broader and more distinct beyond the second segment; a broad virtually entire median dark brown tergal stripe ; basal sternites more uniformly reddish yellow; segments from six outwards brownish black, bases of sixth and seventh yellowed; eighth sternite with two widely separated yellow spots on posterior border. Male hypopygium (Text-fig. 4) with tergite, $t$, transverse, narrowed at midline, posterior border with a conspicuous U-shaped notch to form broad rounded lateral lobes, these more thickened, with abundant very long yellow setae from conspicuous pale punctures ; on ventral surface on either side of midline with a slender glabrous pale rod, generally similar in form but a little smaller than the appendage of the ninth sternite. Ninth sternite with a low obtuse darkened lobe provided with long coarse yellow setae, the appendage, $9 s$, a sclerotized rod, broadest at base, narrowed gradually to the subacute tip, with sparse scattered setae. Outer dististyle, $d$, a flattened club, broadly obtuse at tip, darkened and with abundant setae. Inner dististyle massive, the beak relatively slender, lower beak conspicuous, the entire surface with abundant long pale setae ; near base of style with a low sclerotized flange. Aedeagus, $a$, broad across base, with incurved margins, the compressed-flattened apex slightly dilated. Eighth sternite simple.

Holotype, ô, S.E. Tibet : Rongtö Valley, 6,000 ft., 7.v.I933 (Kingdon-Ward \& Kaulback).

Tipula (Vestiplex) rongtoensis is quite distinct from other large-sized regional species of the subgenus in its hypopygial characters, particularly the tergite, appendage of the ninth sternite, and the dististyles. The most similar such species having similar long pale setae on the dorsal tergal lobes is $T$. $(V$.$) zayulensis sp. \mathrm{n}$. The shape of the appendage of the ninth sternite is suggestive of that of the smaller and otherwise distinct $T$. (V.) ravana Alexander, of the western Himalayas.

\section{Tipula (Vestiplex) spathacea sp. n.}

Size large (wing of male over $20 \mathrm{~mm}$.) ; mesonotal praescutum light yellow, with four grey stripes that are narrowly bordered by light brown; antennae with scape and pedicel yellow, flagellum black ; apices of knobs of halteres light yellow ; femora brownish black, without an outer yellowed ring, tibiae and tarsi brownish black, claws toothed ; wings marbled light yellow and pale brown; basal abdominal segments light yellow, restrictedly patterned with pale brown, outer five segments brownish black; male hypopygium with beak of inner dististyle very slender, divided into two points ; appendage of ninth sternite a very large flattened yellow blade, its outer end dilated, apex obtuse.

Male. Length, about $20 \mathrm{~mm}$.; wing, $21 \mathrm{~mm}$; antenna, about $5 \mathrm{~mm}$.

Frontal prolongation of head orange yellow, outer end above, including the nasus, more pruinose ; palpi with basal segments orange, remainder broken. Antennae of male relatively long ; scape yellow, pedicel clear light yellow, first flagellar segment brown, darker outwardly, remainder of flagellum black; flagellar segments feebly incised, longer than the verticils. Head orange, disk yellow pollinose, centre of vertex and sides of genae weakly darkened. 
Pronotal scutum yellow pollinose, brown anteriorly, scutellum yellow. Mesonotal praescutum with ground light yellow, disk with four grey stripes that are narrowly bordered by light brown, the median edges virtually confluent; scutum with central area light yellow, lobes more brownish grey ; scutellum obscure yellow with a brown central line ; mediotergite light brown on sides, posterior fourth and central area yellowed; pleurotergite brownish yellow, the katapleurotergite clear light yellow ; vestiture of praescutal interspaces and the mediotergite small, of scutellum longer, pale yellow. Pleura orange yellow, pollinose ; dorsopleural membrane light brown. Halteres with stem obscure yellow, knobs dark brown basally, tips broadly light yellow. Legs with coxae and trochanters yellow; femora brownish black, bases narrowly yellowed, without a brightened subterminal ring; tibiae and tarsi brownish black; claws toothed. Wings with a marbled pattern, as common in the subgenus ; light yellow, with major pale brown clouds at arculus, origin of $R s$, cord, beyond midlength and at end of cell $M$, and extensively in cells $C u$, Ist $A$ and $2 n d A$, the darkened pattern subequal in amount to the ground; cells beyond cord pale brown with a pale yellow band extending from costa to cell $R_{5}$; a yellow area in cell $C$ before stigma ; more whitened obliterative areas before stigma and across centre of cell Ist $M_{2}$, this slightly involving cells $R, M_{3}$ and $M_{4}$; cells $C$ and $S c$ uniformly brownish yellow ; veins brown. Small macrotrichia on veins $R_{3}, R_{4+5}$, outer medial veins and distal section of $C u_{1}$, none on $R s$ or Anals. Venation : $R s$ long, about two and a half times $m-c u$; petiole of cell $M_{1}$ slightly longer than $m$.

Basal four abdominal segments light yellow, tergites vaguely trivittate with pale brown, each sternite with a small darkened spot near base; segment five brownish black, narrowly yellowed basally, more extensive on sternite ; outer segments brownish black. Male hypopygium (Text-fig. 6) with the tergite, $t$, large, dorsal plate with each lobe broadly obtuse, margins narrowly darkened and microscopically roughened, apices with very long yellow setae ; lower tergal lobes small, especially their blackened finger-like apices. Appendage of ninth sternite, $9 s$, very large, appearing as a long flattened yellow blade that is constricted before midlength, thence expanded, the apex very broadly obtuse, blade provided with a few yellow setae, exceeding in length the inner dististyle, apparently arising on extreme margin of basistyle rather than on the ninth sternite, the latter produced into a smaller lobe, its apex glabrous. Outer dististyle, $d$, about five times as long as broad, nearly parallel-sided, tip obtuse. Inner dististyle with beak very slender, divided, the longer point obtuse at tip, the slightly shorter subtending spine acute; lower beak including two obtuse blades, directed upward to form a cup-like structure ; on face of style behind the beak with a low brown flange ; near base style produced into flattened plates. Aedeagus, $a$, broad, narrowed outwardly, terminating in a small obtuse point.

Holotype, ô, N.E. Burma : Adung Valley, 8,ooo ft., 30.v.I93I (Kingdon-Ward \& Lord Cranbrook).

Tipula (Vestiplex) spathacea is quite distinct from other known regional species in the unusual appendage of the ninth sternite of the male hypopygium which here is larger than in other members of the himalayensis group. It should be emphasized that this appendage, commonly considered to be borne by the ninth sternite, here appears to arise from the extreme margin of the basistyle rather than the sternite. Very long tergal setae, as described here, occur likewise in various other species, including $T$. (V.) rongtoensis sp. n. and $T$. (V.) zayulensis sp. n.

\section{Tipula (Vestiplex) subscripta Edwards}

Tipula subscripta Edwards, 1928, Ann. Mag. Nat. Hist. (1о) 1 : 689.

The type was from Yunnan, China, taken east of Janula, II,000 ft., 24.vi.I922, by J. W. Gregory. 
S.E. Tibet : Shugden Gompa, Ngagong, I2,000-13,000 ft., I8-25.viii.I933 (Kingdon-Ward) ; on labels written "Shiuden Gompa". Du Chu Valley, 13,000I3,500 ft., I3.vii.I936 (Kaulback) ; Posho, I3,000-I4,000 ft., 24-29.vii.I936 (Kaulback) ; Ngagong Chu, Pome, I2,000 ft., I2.viii.I935 (Kaulback).

\section{Tipula (Vestiplex) zayulensis sp. $\mathrm{n}$.}

Allied to rongtoensis ; size large (wing of male about $20 \mathrm{~mm}$.) ; mesonotum grey, praescutum with four stripes that are bordered by darker ; femora brown with a yellow subterminal ring ; wings medium brown, patterned with darker brown and cream-coloured areas, including a large postarcular darkening ; male hypopygium with dorsal lobes of tergite rounded, conspicuously hairy, ventral armature consisting of a narrow plate, its blackened margin microscopically serrulate; appendage of ninth sternite glabrous ; cerci of ovipositor with smooth margins.

Male. Length, about I $7-18 \mathrm{~mm}$; wing 20-21 mm.; antenna, about $4 \mathrm{~mm}$.

Female. Length, about 29-30 mm.; wing, 23-24 mm.

Frontal prolongation of head above yellow, dusted with whitish, darker on sides ; nasus elongate ; palpi brown, terminal segment brownish black. Antennae short ; scape and pedicel yellow, first flagellar segment yellowish brown, succeeding two or three segments bicoloured, the small basal enlargements dark brown, the stems yellow, becoming progressively darker on outer segments, becoming uniformly dark brown; segments a trifle exceeding their longest verticils. Head brownish yellow, heavily light grey pruinose, centre of posterior vertex vaguely more darkened ; vertical tubercle rounded, entire.

Pronotum light grey, vaguely patterned with light brown. Mesonotal praescutum with the restricted ground light grey, with two intermediate darker grey stripes and more brownish grey laterals, bordered by brown, the inner edges of all stripes darker than the subobsolete outer margins ; scutum light grey, each lobe with two confluent brown areas, the larger posterior one vaguely bordered by darker brown ; scutellum and mediotergite grey, with a more or less distinct central brown line. Pleura grey, the anepisternum and ventral sternopleurite darker grey ; dorsopleural membrane yellow. Halteres with stem yellow, knob dark brown, apex restrictedly obscure yellow. Legs with coxae grey ; trochanters yellow ; femora brown, more yellowed basally, tips broadly black, preceded by a clearer yellow ring ; tibiae and tarsi brown ; claws of male with an acute subbasal spine. Wings medium brown, with a restricted darker brown and more extensive pale pattern ; the dark areas include a large postarcular marking extending from costa to $C u$, involving the bases of cells $R$ and $M$; other darkenings at origin of $R s$, stigma and a confluent seam over anterior cord; pale areas include the prearcular field, a large area near bases of cells $R$ and $M$ and other smaller marks near outer ends of these cells encroaching on adjacent cells ; beyond the cord a short but conspicuous band beyond stigma, extending from $C$ through cell $R_{5}$; pale marginal spots in outer ends of both Anal cells ; obliterative area across base of cell Ist $M_{2}$, including also parts of cells $R$ and $M_{3}$; pale prestigmal spot very small ; veins light brown. Outer longitudinal veins with macrotrichia, lacking on $R s, M$, all sections of $M_{1+2}, M_{3+4}$ and basal section of $M_{3}$; vein Ist $A$ with one or few trichia at end, 2nd $A$ with a series on outer half; no trichia on prearcular Anal veins. Venation : Rs from one-half to about three-fourths longer than $m-c u$; petiole of cell $M_{1}$, subequal to or shorter than $m$.

First abdominal tergite buffy, darkened medially on posterior half; tergites two to five yellow, trivittate with dark brown, the sublateral darkenings interrupted at posterior ends of segments, extreme lateral borders clearer grey ; basal sternites yellow, lateral borders grey ; outer segments passing into brownish black, styli of hypopygium brownish yellow; in a paratype male, the basal abdominal segments are almost uniformly orange yellow, the dark pattern obsolete or virtually so. Ovipositor with margins of cerci smooth, without serrations, on basal half fringed with delicate setae; hypovalvae relatively long, compressed-flattened. 

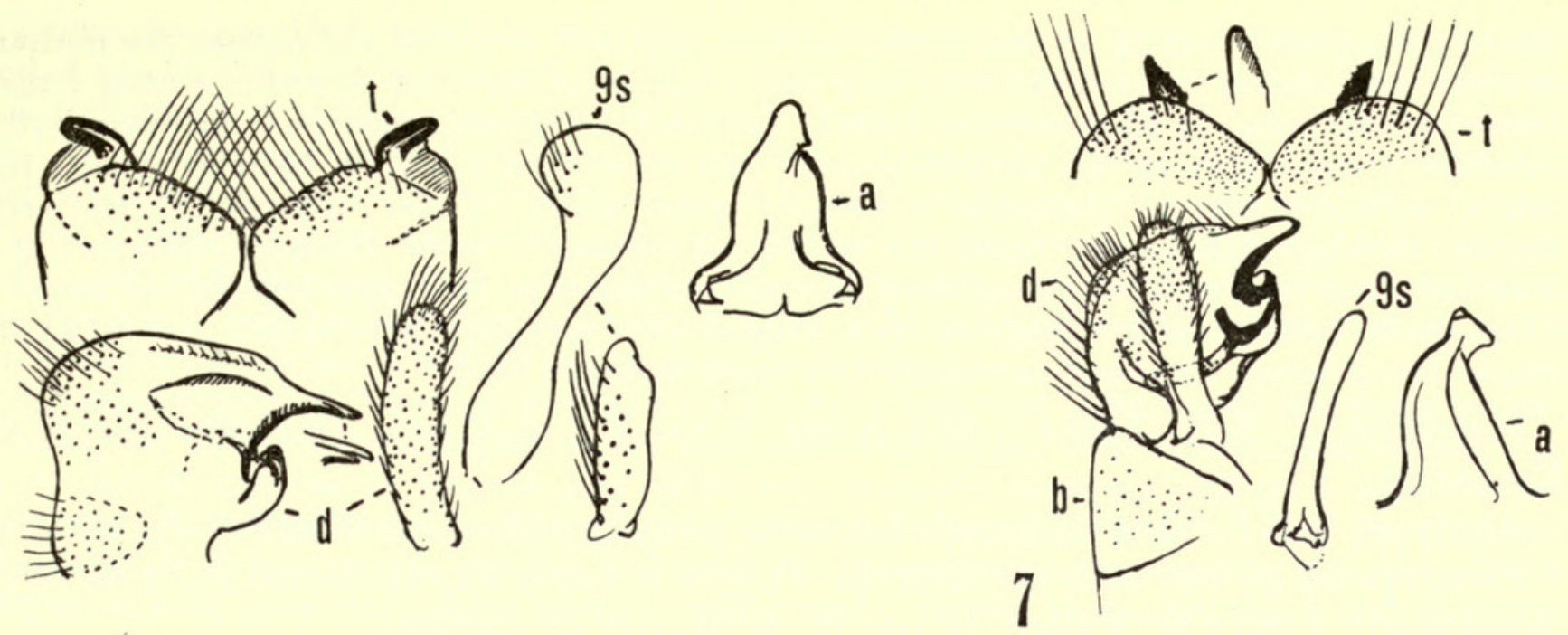

0
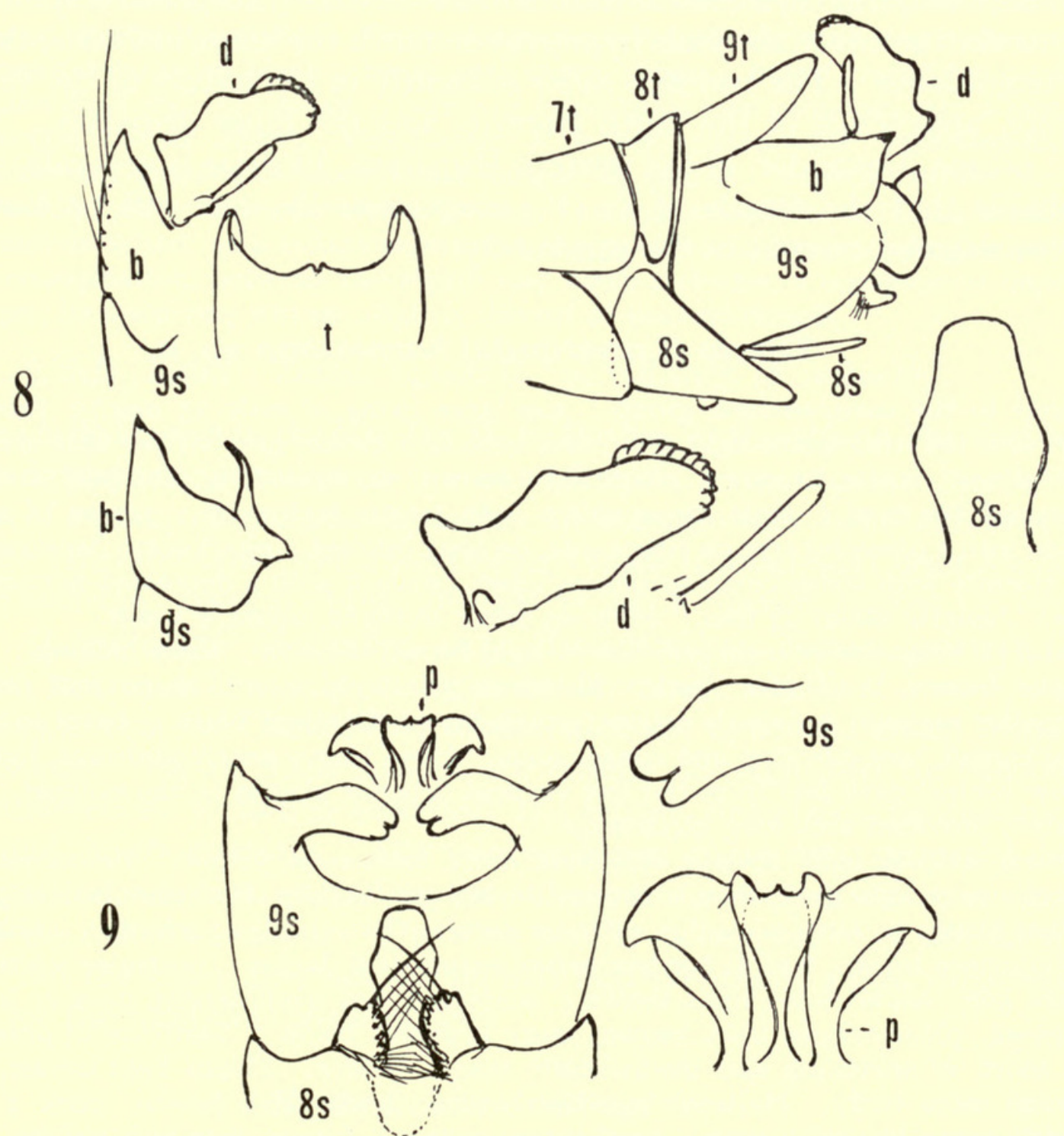

Figs. 6-9. (TIPULINAE). 6, Tipula (Vestiplex) spathacea sp. n. ; male hypopygium. 7, Tipula (Vestiplex) zayulensis sp. n. ; male hypopygium. 8, 9, Tipula (Lunatipula) barnesiana sp. n. ; male hypopygium.

(Symbols : $b$, basistyle ; $d$, dististyle ; $p$, phallosome ; $s$, sternite ; $t$, tergite.) 
Male hypopygium (Text-fig. 7) with upper lobes of tergite, $t$, very low and obtuse, the median emargination shallow ; lobes with very long pale erect setae, directed dorsad ; ventral tergal armature consisting of small narrow plates, the mesal edge blackened and microscopically serrulate. Ninth sternite, $9 s$, with long setae, the appendage a narrow flattened blade, tip obtuse, surface glabrous. Basistyle, $b$, without apical spines. Outer dististyle, $d$, relatively narrow, its length about five times the width, apex obtuse. Inner dististyle compact, the beak and lower beak separated by a small circular emargination, the border heavily blackened ; a low dorsal crest; outer surface of style fringed with very long pale setae. Aedeagus, $a$, simple, broad-based, narrowed outwardly to a small flattened head.

Holotype, ô, S.E. Tibet : Ata Kang, 8,000 ft., 29.v.I933 (Kingdon-Ward \& Kaulback).

Allotype, o, S.E. TIBET : Zayul, 8,00o ft., 3.vi.I933 (Kingdon-Ward \& Kaulback).

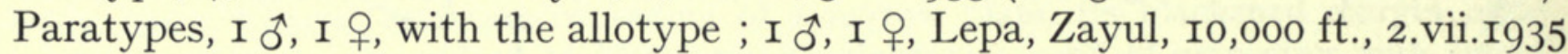
(Kaulback) ; Lepa Chu Valley, I2,00o ft., 6.vii.I935 (Kaulback).

Tipula (Vestiplex) zayulensis is most similar to $T$. $(V$.) rongtoensis sp. n., which has the general structure of the male hypopygium much the same, including the unusually hairy tergal lobes. The two flies differ evidently in the nature of the ventral tergal armature, appendage of the ninth sternite, and the inner dististyle. The smaller $T$. $(V$.) ravana Alexander, of the western Himalaya, likewise is generally similar. It is probable that the female of $T$. $(V$.$) rongtoensis likewise will be found to have$ smooth-margined cerci as in the present fly.

\section{Tipula (Lunatipula) barnesiana sp. $\mathrm{n}$.}

Belongs to the variipetiolaris group ; size large (wing of male $25 \mathrm{~mm}$.) ; mesonotal praescutum with the interspaces light grey, disk with four darker grey stripes that are bordered by darker brown; nasus lacking ; wings light brown, variegated by whitened areas, chiefly at and beyond the cord; male hypopygium with tergite tridentate; region of ninth sternite produced into a powerful arm on either side, its apex bilobed ; phallosome depressed-flattened ; eighth sternite with conspicuous setiferous lobes, beneath with a depressed-flattened tongue.

Male. Length, about $24 \mathrm{~mm}$.; wing, $25 \mathrm{~mm}$.; antenna, about $5 \cdot 2 \mathrm{~mm}$.

Frontal prolongation of head grey above, light brown beneath ; nasus lacking ; first segment of palpus brown, remainder black. Antennae relatively long; scape and pedicel yellow, first flagellar segment brownish yellow, remainder of flagellum black; basal enlargements of segments small, verticils long and conspicuous. Head above nearly glabrous, light grey, with a narrow central dark line from the low vertical tubercle almost to the occiput ; genae more infuscated, provided with long black setae.

Pronotal scutum light brown, scutellum more testaceous yellow. Mesonotal praescutum with interspaces light grey, disk with four darker grey stripes, the intermediate pair bordered by darker brown to form a median vitta on anterior two-thirds of sclerite ; sublateral stripes more uniformly brown, lateral borders before suture still darker ; posterior sclerites of notum brownish grey, scutal lobes light brown; scutellum and mediotergite more or less patterned with brown, pleurotergite light brown, more pruinose below; vestiture of praescutal interspaces short, of scutellum and mediotergite longer, yellow. Pleura light brown, dorsopleural membrane more buffy. Halteres brownish yellow, knob dark brown, apex a little paler. Legs with coxae brownish grey; trochanters yellow; femora brownish yellow, tips scarcely darkened ; tibiae brownish yellow, tips very narrowly infuscated, tarsi passing into black, terminal segment brownish yellow; claws small, toothed. Wings with ground light brown, costal border and cells beyond cord somewhat darker brown ; a conspicuous white pattern chiefly at and beyond the cord, the principal area from outer end of cell $R$, crossing cell Ist $M_{2}$, 
reaching the margin in cells $M_{3}$ and $M_{4}$; other whitened areas beyond stigma, near outer end of cell $R_{5}$ and near base of cell $2 n d M_{2}$; a whitened seam along vein Ist $A$, near its outer end including also cell $\mathrm{Cu}$; a further whitened streak near margin of cell ist $A$ closer to vein 2nd $A$; stigma and a restricted area at anterior cord slightly darker brown ; veins brown, slightly yellowish brown in the whitened areas. Longitudinal veins beyond cord with macrotrichia, lacking on outer half of $R_{1+2}, R s, M$ and basal section of $C u_{1}$, sparse and scattered on outer ends of both Anal veins. Venation : $R_{1+2}$ preserved ; $R_{2}$ relatively long, about threefourths $r-m$; cell Ist $M_{2}$ elongate, basal section of $M_{3}$ about one-half longer than $m$; cell $M_{1}$ from about one and a half to nearly twice its petiole.

Abdominal tergites brownish yellow, with a poorly indicated light brown middorsal stripe, interrupted at posterior margins of the segments, and darker brown sublateral stripes, the outer lateral margins of tergites grey pruinose; sternites brownish yellow, a little darker medially; outer segments, including hypopygium, more yellowish brown. Male hypopygium (Text-figs. 8 , 9) with tergite, sternite and basistyle all completely separated by sutures. Ninth tergite, $t$, with posterior border broadly emarginate; lateral angles produced into flattened blades, median area slightly produced, divided medially by a microscopic notch. Region of ninth sternite, $9 s$, on either side produced mesad into a powerful arm that is directed toward the midline, apex bilobed, blackened. Outer dististyle, $d$, cylindrical, with short setae. Inner dististyle a powerful darkened blade ; beaks very short, obtuse ; dorsal crest lying far distad, low, strongly furrowed and corrugated ; region of outer basal lobe produced into a lobe, with a lower projection farther distad. Phallosome, $p$, a very conspicuous depressed-flattened structure with lateral blades and more dorsal flanges, as figured. Eighth sternite, $8 s$, large, narrowed outwardly, posterior border with a U-shaped emargination filled with pale membrane ; lateral lobes semi-detached, with conspicuous setae, the most lateral longer and subfasciculate; from base of emargination, between the eighth and ninth sternites, a conspicuous depressedflattened tongue, its apex very obtuse, slightly dilated at near midlength.

Holotype, ô, S.E. Tibet : Zayul, I4,00o ft., 30.viii.r935 (Kaulback).

The species is dedicated to the late Dr. H. F. Barnes, authority on the Cecidomyiidae, who made important studies on the crane-flies of Caernarvonshire, north Wales. The fly is one of a group of four known species, all from the high mountains of western China and the Tibetan border, the others being Tipula (Lunatipula) justa Alexander, I935, from Szechwan, western China, altitude I5,200 ft., taken August I4, I933, by Graham ; T. (L.) minensis Alexander, I934, from Minshan, Kansu, western China, altitude 3,000 metres, taken July 20, I930, by Hummel, and $T$. (L.) variipetiolaris Alexander, I933, from the China-Tibet border, altitude I4,000 ft., taken August I4, I930, by Graham. All of these species are readily distinguished by conspicuous hypopygial differences, including especially the tergite, dististyles, phallosome, and the eighth and ninth sternites. The variipetiolaris group was proposed by the writer in 1935 and has been placed in the subgenus Lunatipula where it disagrees especially in the naked squamae. The wing pattern is suggestive of certain species of Acutipula but the group does not belong here and eventually a new subgenus may be required for the reception of the species.

\section{Nephrotoma dutti sp. n.}

Mesonotal praescutum with three polished ferruginous stripes, pleura yellow, variegated with more ferruginous areas; legs brownish yellow, tarsi passing into brown; wings very pale yellow, costal border more saturated yellow ; stigma medium brown, with trichia, cell $M_{1}$ sessile; abdomen brownish orange, with a broad brownish black subterminal ring; male 
hypopygium with tergal lobes rounded, with abundant spicules, the lateral ends produced into a strong curved arm ; inner dististyle massive, region of dorsal crest produced into a low triangular point ; gonapophyses elongate-oval, shorter than the aedeagus.

Male. Length, about $\mathrm{I}^{-\mathrm{I}} 4 \mathrm{~mm}$; wing, $10.5^{-\mathrm{I} 2} \cdot 5 \mathrm{~mm}$; antenna, about $4.8-5 \mathrm{~mm}$.

Female. Length, about $\mathrm{I} 4 \mathrm{~mm}$.; wing, $\mathrm{I} 2 \mathrm{~mm}$.

Frontal prolongation of head light yellow, outer half of dorsum, with the long nasus, infuscated ; palpi yellow throughout. Antennae with scape light yellow, pedicel more testaceous yellow, flagellum black ; flagellar segments in male strongly incised, the outer enlargements longer than the basal swellings, segments exceeding their verticils. Head light orange yellow, posterior vertex with a very delicate brown median line that does not reach the occiput, the occipital brand barely differentiated; vertical tubercle prominent, weakly divided medially ; vestiture of vertex small, black.

Pronotum uniformly light yellow. Mesonotal praescutum polished yellow with three polished ferruginous stripes, the centre of the median area vaguely paler, lateral stripes straight ; scutum yellow, each lobe with two nearly confluent ferruginous areas ; scutellum very slightly darkened, parascutella yellow ; postnotum, including pleurotergite, yellow, mediotergite with posterior third vaguely more ferruginous; vestiture of thoracic notum very small and sparse, best indicated on scutellum and mediotergite. Pleura yellow, variegated with more ferruginous areas on anepisternum, ventral sternopleurite and ventral meron. Halteres with stem yellow, knob infuscated. Legs with coxae and trochanters yellow; femora and tibiae brownish yellow, tips of latter narrowly darkened; tarsi passing into brown. Wings (Text-fig. ro) very pale yellow, prearcular and costal fields slightly more saturated yellow; stigma medium brown ; a vague pale brown cloud on anterior cord ; veins brown, more yellowed in the brightened areas. Stigma with rather numerous macrotrichia. Venation : cell $M_{1}$ narrowly to broadly sessile ; $m-c u$ at or just before fork of $M_{4}$.

Abdomen brownish orange, tergites slightly more darkened medially, the actual borders pale ; sternites more uniformly orange yellow ; seventh and eighth segments brownish black to form a conspicuous ring; hypopygium yellowed. In female, abdomen obscure orange yellow with a central brown stripe, seventh and eighth segments blackened. Ovipositor with genital shield and cerci yellow, tips of the latter narrowly obtuse. Male hypopygium (Text-fig. I4) with the tergite, $t$, transverse, posterior border shallowly emarginate, with low broad darkened lobes that bear abundant blackened spicules, those on cephalic margin longer and more concentrated ; outer lateral end of each lobe produced into a strong curved arm, its apex with a few further spicules. Outer dististyle, $d$, expanded beyond base, narrowed to the obtuse tip, the length is little less than three times the greatest width. Inner style massive, beak obtuse, its lower part heavily blackened, produced into an acute point; lower beak blackened, broadly obtuse ; region of dorsal crest produced into a triangular point, concolorous with the remainder of style, not appearing as pale membrane as in many species ; no well-developed outer basal lobe, the area provided with a few strong setae. Phallosome, $p$, with gonapophyses elongate-oval, with both ends obtuse, shorter than the aedeagus. Eighth sternite large, posterior border feebly convex to subtruncate, median area filled with pale membrane, provided with relatively few strong setae of moderate length.

Holotype, ô, Pakistan : Murree, 7,500 ft., I8.vi. (Dutt).

Allotopotype, 오, same data.

Paratopotype, ㅇ, same data.

Paratype, ô, Kumaon : Tungnath, Pauri Garhwal, 9,000 ft., I.vi.I958 (Schmid). Edwards indicated that there was a further male in the British Museum (Natural History).

The specific name, Nephrotoma dutti, was suggested by Edwards, in honour of the collector of the type. The ferruginous praescutal stripes distinguish the fly from other regional members of the genus with the exception of the otherwise very 
different $N$. concolorithorax (Brunetti). It much resembles the widespread North American $N$. ferruginea (Fabricius) but is entirely different in the hypopygial structures. I am including this species in the present paper in order to complete the record of the present series of specimens from the British Museum.

\section{Nephrotoma perhorrida Alexander}

Nephrotoma perhorrida Alexander, 1942, Rec. Indian Mus. 44:50-52, fig. Io (venation, ơ hypopygium).

The types were from Cherrapunji, Assam, 4,00o ft., taken by Sircar. A metatype from the type locality, taken June I8, I9I8, was presented to the British Museum by T. B. Fletcher, B.M. I925-546.

\section{LIMONIINAE Limonia (Limonia) propior sp. n.}

Mesonotal praescutum obscure yellow, with six brown stripes including the lateral borders ; femora yellow, tips brownish black, subterminal ring yellow ; wings pale yellow, marbled with extensive pale brown clouds, stigma solidly darkened; $m-c u$ before fork of $M$; abdomen brown, posterior borders of segments, especially the sternites, yellow.

Female. Length, about 7.5-9.5 mm.; wing, I I-I $3 \mathrm{~mm}$.

Rostrum and palpi black. Antennae with scape black, pedicel brown, more yellowed in paratype; flagellum dark brown, segments longer than the verticils. Head dark brown, with black setae ; anterior vertex about two and a half times the diameter of scape.

Pronotum light brown, more yellowed on sides. Mesonotal praescutum obscure yellow, with six brown stripes including the lateral borders ; intermediate stripes very narrowly separated by a capillary obscure yellow median vitta ; in the paratype the lateral borders are only slightly darkened so the praescutum appears quadrivittate ; scutum broadly pale yellow medially, lobes dark brown, connected across the suture with the sublateral praescutal stripes ; scutellum and postnotum dark liver brown. Pleura and pleurotergite liver brown. Halteres with stem and apex of knob yellowed, base of latter infuscated. Legs with coxae dark brown ; trochanters obscure yellow ; femora yellow basally, tips brownish black, preceded by a slightly broader yellow ring, the central part suffused with paler brown; tibiae and basitarsi obscure yellow, tips narrowly darkened, outer tarsal segments blackened. Wings (Text-fig. II) with the restricted ground pale yellow, marbled with extensive pale brown clouds over the whole surface, slightly more extensive than the ground; cell $S c$ uniformly yellow, stigma solidly darkened; veins brown. Venation: $S c$ long, $S c_{2}$ ending about opposite one-third $R_{2+3}, S c_{1}$ shorter, erect; $R_{1+2}$ subequal to $m-c u$; cell Ist $M_{2}$ subequal to distal section of vein $M_{3} ; m-c u$ some distance before fork of $M$, in the type the distance subequal to $m-c u$, in the paratype about one-third this length.

Abdominal tergites brown, the posterior borders of the intermediate segments narrowly and vaguely pale; sternites conspicuously bicoloured, dimidiate, bases brown, apices broadly yellow, on sternites five to seven the pale borders narrowly more obscure yellow. Ovipositor with cerci small, very slender, tips acute ; hypovalvae broad, light yellow, tips acute.

Holotype, ㅇ, S.E. Tibet : Zayul, Di Chu Valley, I2,000 ft., 25.viii.I933 (KingdonWard \& Kaulback).

Paratype, ㅇ, N.E. Burma : Adung Valley, 28.ix.I93I (Kingdon-Ward \& Lord Cranbrook). 
In its general appearance, especially the coloration of the wings and legs, the present fly resembles Limonia (Limonia) kashmirica (Edwards), widespread over the Himalayan region into western China. It differs especially in the thoracic and abdominal coloration and in the venation. In kashmirica $m-c u$ lies far beyond the fork of $M$, at near one-third to one-half the length of cell Ist $M_{2}$.

\section{Limonia (Limonia) vajra Alexander}

Limonia (Limonia) vajra Alexander, I957, Jour. N.Y. Ent. Soc. 65 : 152-I53.

The types were from Simbhanjang Pass, Nepal, altitude 8, I90 ft., collected in July and October 1956 by Edward I. Coher. Known also from Manipur, Hkayam Boum, altitude 7,500 ft., taken June 20, I960, by Fernand Schmid.

N.E. Burma : Adung Valley, 8,000 ft., I2.vi.I93I (Kingdon-Ward \& Lord Cranbrook).

The single female agrees closely with the types with the exception of the leg coloration, the darkened femoral ring being so pale and reduced in size as to virtually be lacking.

\section{Limonia (Libnotes) kaulbackiana sp. $\mathrm{n}$.}

Size large (wing of male about $28 \mathrm{~mm}$.) ; general coloration of thorax yellow, praescutum with four brown stripes, the intermediate pair narrowly separated; halteres light yellow, knob dark brown; legs very long, femora yellow, tips weakly infuscated ; wings yellowed, very restrictedly patterned with brown, appearing as narrow seams over cord and outer veins ; a supernumerary cross-vein in cell $R_{3}$; abdomen yellow with a brownish black subterminal ring.

Male. Length, about I $8 \mathrm{~mm}$; wing, about $28 \mathrm{~mm}$. Fore leg, femur, $22 \mathrm{~mm}$; tibia, $26 \mathrm{~mm}$., tarsus, $22 \mathrm{~mm}$. Middle leg, femur, $22 \mathrm{~mm}$.; tibia, $23.5 \mathrm{~mm}$.; tarsus, $12 \mathrm{~mm}$. Hind leg, femur, $24 \mathrm{~mm}$.; tibia, $25 \mathrm{~mm}$.; tarsus, $14 \mathrm{~mm}$.

Rostrum moderately long, exceeding the antennal scape, dark brown above, paler brown beneath ; maxillary palpi short, light brown. Antennae with scape and pedicel light brown, flagellar segments brown basally, apices obscure yellow, narrowed basally, gradually widened outwardly, with short verticils at the broadest part; terminal segment about one-fourth longer than the penultimate. Head yellow pollinose, posterior vertex restricted, weakly darkened medially.

Pronotum light yellow medially, weakly darkened on sides. Mesonotal praescutum yellow with four medium brown stripes, the intermediate pair long, separated by a capillary ground line, lateral stripes short and broad; posterior sclerites of notum pale yellow, scutal lobes weakly darkened. Pleura yellow, including the dorsopleural region, without evident darker pattern excepting a small area on propleura. Halteres light yellow, knob dark brown. Legs with coxae fulvous yellow; trochanters yellow; femora yellow, tips broadly but weakly infuscated; tibiae and tarsi brown; claws conspicuously toothed, including a longer outer spine and a comb of six denticles, progressively smaller toward the base ; legs very long, as shown by the measurements, fore tarsi much longer than the others. Wings yellowed, stigma and costal border more saturated yellow, the former narrowly brown at either end ; very narrow to scarcely evident brown seams over the cord and the veins beyond; veins yellow, light brown in the darkened seams. Venation : $R_{2}$ about two-thirds the combined $R_{1+2}$ and free tip of $S c_{2}$ beyond it ; supernumerary crossvein in cell $R_{3}$ variable in position, from nearly opposite $R_{2}$ to about its own length before this ; cell Ist $M_{2}$ elongate, base of cell $2 n d M_{2}$ at 
near three-fourths the length of cell Ist $M_{2}, m$ long, strongly angulated and weakly spurred at near one-third the length; $m-c u$ at near one-third $M_{3+4}$; Anal veins converging basally, 2nd $A$ sinuous.

Abdomen, including hypopygium, yellow, the seventh and eighth segments brownish black, the seventh sternite slightly paler.

Holotype, ô, Upper Burma : Seinghku Valley, 4,50o ft., I5.v.I935 (Kaulback).

I dedicate this species to the collector of the type and other interesting species in the present series of specimens, Mr. Ronald J. H. Kaulback. This large and conspicuous fly is quite distinct from other regional species of Libnotes that have a supernumerary crossvein in cell $R_{\mathbf{3}}$ of the wings, including Limonia (Libnotes) fuscinervis (Brunetti) and L. (L.) transversalis (de Meijere). In its nearly unpatterned wings it is more like the latter species, a much smaller fly described from eastern Java. Other very large species known from Formosa and Japan that have a supernumerary crossvein in cell $R_{3}$ have a second such element in cell $R_{5}$. If the subgenus Laosa Edwards is to be recognized as valid it will have to include all of these various species having supernumerary crossveins in various cells of the radial field of the wing.

\section{Limonia (Discobola) armorica Alexander}

Limonia (Discobola) armorica Alexander, I942, Rec. Indian Mus. 44 : 54.

N.E. Burma : Adung Valley, I2,000 ft., 5-26.viii., I.x.I93I (Kingdon-Ward \& Lord Cranbrook) ; 4 ๙ิ 우.

S.E. Tibet : Rongtö Valley, 7,000-9,000 ft., xi.I933 (Kingdon-Ward) ; one specimen labelled “ wet night” ; 2 ธิธิ.

The Tibetan specimens agree closely with material from the Adung Valley, differing in slight features of the male hypopygium, particularly the less developed tergal lobes. A single male from the Adung Valley (August 26, I93I) is unusually large but appears to be conspecific (length, about I $2 \mathrm{~mm}$.; wing, $\mathrm{I} 4.5 \mathrm{~mm}$.).

\section{Limonia (Rhipidia) near synspilota Alexander}

Limonia (Rhipidia) synspilota Alexander, I935, Philippine Jour. Sci. 56 : 548-550, pl. I, fig. I6 (venation), pl. 3, fig. 39 (male hypopygium).

N.E. Burma : Adung Valley, I2,00o ft., I2-I6.viii.I93I (Kingdon-Ward \& Lord Cranbrook) ; 3 우우.

S.E. TibeT : Rongtö Valley, 7,00o ft., Ir.xi.I933 (Kingdon-Ward) ; 2 우.

The females that are available are generally similar to the types, taken at various stations in Kashmir, but with the discovery of the male may possibly prove to be distinct.

\section{Limonia (Dicranomyia) baileyana sp. n.}

General coloration of mesonotum greyish yellow, praescutum with a dark brown median stripe, pleura and pleurotergite yellow with a sparse white pruinosity ; head clear light grey ; wings subhyaline, stigma oval, very pale brown, $S c_{1}$ long, about three-fourths $R s$; male hypopygium with posterior border of tergite truncate, with a U-shaped emargination ; basistyle with a secondary lobe on mesal face ; rostral spines very long, rostrum with a lobule at base of outer margin. 

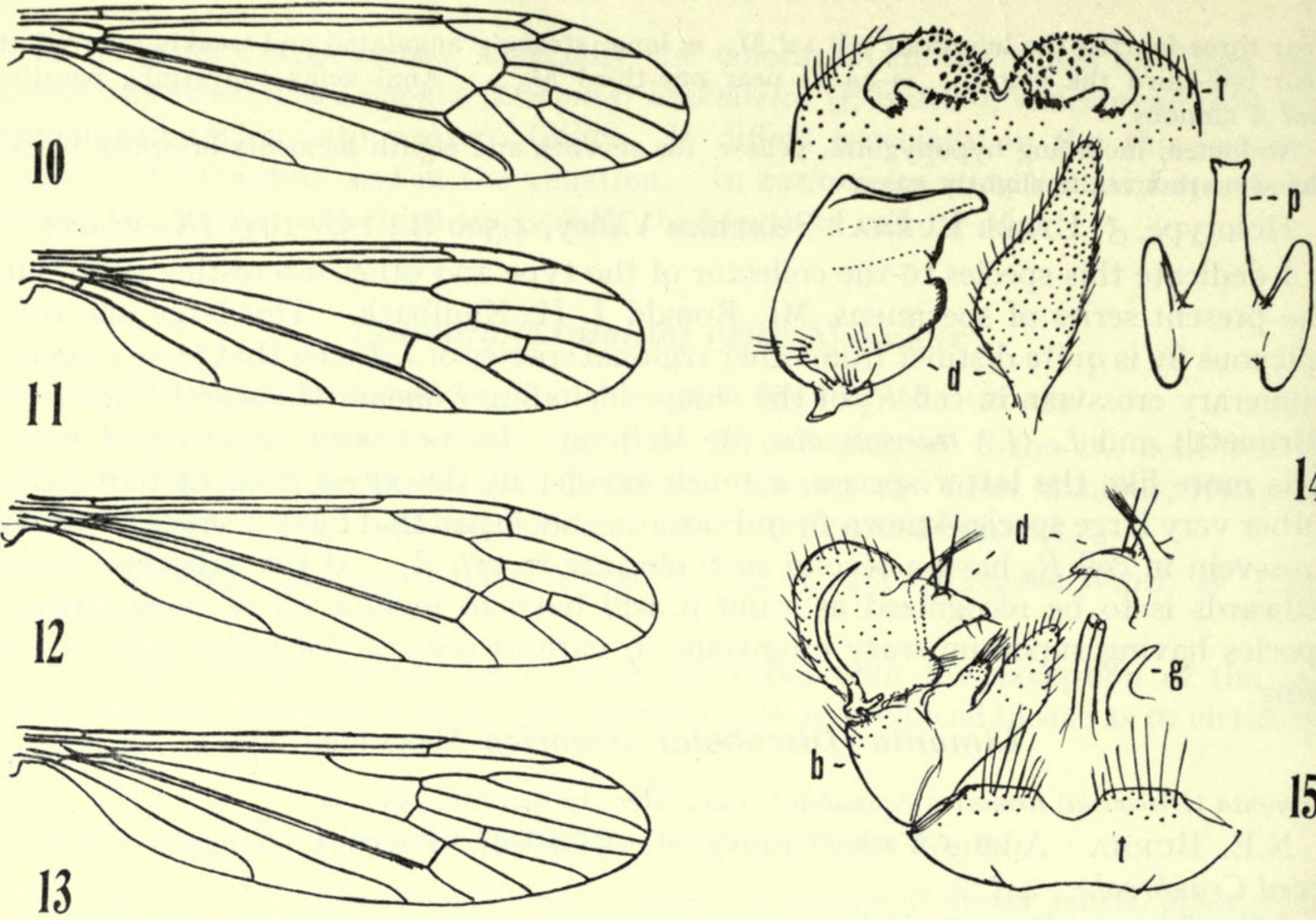

14
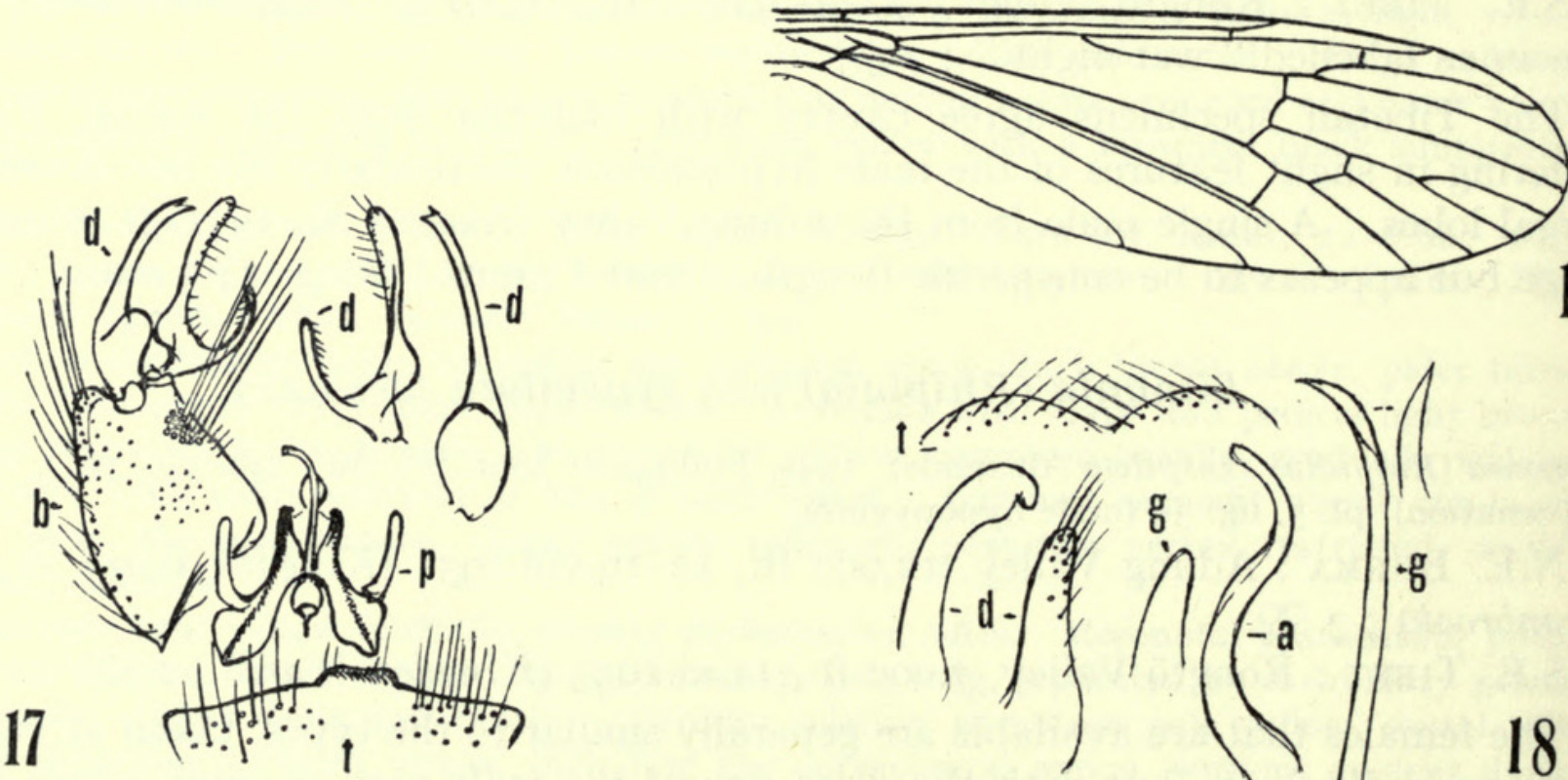

16

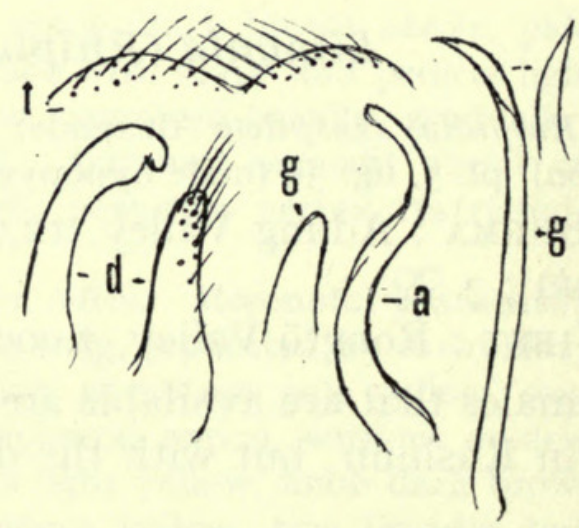

15

Figs. Io-r8. (TIPULINAE, LIMONIINAE). Io, Nephrotoma dutti sp. n. ; venation. II, Limonia (Limonia) propior sp. n. ; venation. I2, Limonia (Dicranomyia) baileyana sp. n. ; venation. I3, Phyllolabis pallidivena sp. n. ; venation. I4, Nephrotoma dutti sp. n. ; male hypopygium. I5, Limonia (Dicranomyia) baileyana sp. n. ; male hypopygium. I6, Limnophila (Prionolabis) kingdonwardi sp. n. ; venation. I7, Limnophila (Prionolabis) kingdonwardi sp. n.; male hypopygium. 18, Antocha (Antocha) yatungensis sp. $\mathrm{n}$. ; male hypopygium.

(Symbols: $a$, aedeagus; $b$, basistyle; $d$, dististyle; $g$, gonapophysis; $p$, phallosome: $t$, tergite.) 
Male. Length, about $7 \mathrm{~mm}$; w wing, $8 \mathrm{~mm}$.

Female. Length, about 6.5-7 mm.; wing, 8-8.8 $\mathrm{mm}$.

Rostrum brown, palpi black. Antennae with scape and pedicel black, flagellum dark brown ; flagellar segments oval, narrowed apically into short pedicels, longest verticils exceeding the segments. Head clear light grey ; anterior vertex nearly two and a half times the diameter of scape.

Cervical region and median area of pronotum dark brown, sides yellowed. Mesonotal praescutum broadly greyish yellow on sides, central region dark brown, paler and vaguely divided on posterior third; scutal lobes greyish brown, median area yellowish grey ; scutellum and mediotergite light brown, margins yellowed. Pleura and pleurotergite yellow, with a sparse white pruinosity. Halteres long, stem light brown, base yellowed, knob weakly more infuscated. Legs with coxae and trochanters yellow ; femora yellow, tips narrowly pale brown ; tibiae and tarsi light brown; claws nearly straight, with a major outer tooth, its tip obtuse, with three progressively smaller more basal denticles. Wings (Text-fig. I2) subhyaline, stigma oval, very pale brown ; veins brown. Venation : $S c_{1}$ ending opposite origin of $R s, S c_{1}$ long, about three-fourths $R s ; R_{2}$ in virtual transverse alignment with free tip of $S c_{2}$; cell Ist $M_{2}$ subequal in length to vein $M_{4} ; m-c u$ at or just before fork of $M$.

Abdominal tergites, with the hypopygium, dark brown, basal sternites yellowed. Male hypopygium (Text-fig. I5) with tergite, $t$, narrowly transverse, posterior border truncate with a conspicuous U-shaped median emargination, the marginal setae very long. Basistyle, $b$, with setae at outer end only, ventromesal lobe elongate, broadest at near midlength, on mesal face immediately beyond the lobe with a smaller lobule tipped with long yellow setae, the apical ones stout, subfasciculate. Dorsal dististyle a curved rod, gradually narrowed into a long acute point. Ventral dististyle, $d$, slightly less in total area than the basistyle ; body pale, region of rostral prolongation more darkened ; prolongation yellowed, apex subacute ; rostral spines very long, straight, from a low common tubercle, each spine fully one-half as long as the dorsal dististyle ; on mesal face of style at base with a low lobe bearing long yellow setae, extended across base of prolongation to form a more slender lobe at base of outer margin of prolongation, tipped with long yellow setae. Gonapophysis, $g$, with mesal-apical lobe slender, gently curved. Aedeagus slender, both genital apertures terminal.

Holotype, ô, Tibet : Chumbi Valley, ro.vi.I928 (F. M. Bailey).

Allotype, 웅 TiBet : Yatung, I2,000 ft., 2r.ix.I928 (Bailey).

Paratype, ㅇ, Tiвeт : Gyantse, I3,000 ft., I3.vii.I928 (Bailey).

Limonia (Dicranomyia) baileyana is named after the collector, Lt. Col. F. M. Bailey, who made early collections of insects in Tibet. Other generally similar Asiatic species with modified male hypopygia include $L$. (D.) vamana Alexander, L. (D.) veternosa Alexander, and many others recently described by the writer from the Himalayas, all showing strong specific characters in the male hypopygium, particularly the tergite, basistyle and ventral dististyle.

\section{Antocha (Antocha) nebulipennis immaculata Alexander}

Antocha (Antocha) nebulipennis immaculata Alexander, 1938, Philippine Jour. Sci. 66 : 319, pl. 2, fig. 29 (male hypopygium).

The type was from Mount Omei, Szechwan, China, altitude 9,00o ft., taken June I2, I937, by Tsen, a collector employed by the late George M. Franck.

N.E. Burma : Adung Valley, I2,000 ft., 8-r6.viii.I93 I (Kingdon-Ward \& Lord Cranbrook). 


\section{Antocha (Antocha) yatungensis sp. n.}

Size medium (wing of male $5.5 \mathrm{~mm}$.) ; general coloration of entire body yellow ; antennae and halteres yellow throughout ; femora white, tips very narrowly and abruptly black, claws with a single stout spine ; wings broad, whitish subhyaline, veins comprising the cord brown ; male hypopygium with apex of outer dististyle broadly obtuse, decurved ; aedeagus and the longer gonapophyses conspicuous, tip of latter acute.

Male. Length, about $4.5 \mathrm{~mm}$. ; wing, $5.5 \mathrm{~mm}$.

Rostrum and palpi pale yellow. Antennae relatively short, pale yellow throughout ; flagellar segments oval, the terminal and more proximal segments with long verticils, the remaining segments with numerous short black setae. Head light yellow.

Thorax light fulvous yellow, unpatterned. Halteres pale yellow. Legs with coxae and trochanters pale yellow ; remainder of legs long, femora white, apex very narrowly and abruptly black ; tibiae and tarsi white, outer tarsal segments weakly darkened; claws with a single stout spine close to base. Wings broad, whitish subhyaline, veins comprising the cord and outer end of cell Ist $M_{2}$ brown, remaining veins whitened. Venation : $R_{2}$ sinuous, $R_{1+2}$ only about onethird as long ; $R_{2+3}$ about two-thirds $R_{2}$, basal section of $R_{4+5}$ long, nearly twice $r-m$; cell Ist $M_{2}$ narrowed at base, $m$ about one-half longer than basal section of $M_{3} ; m$-cu slightly more than its own length before fork of $M$.

Abdomen, including hypopygium, pale yellow. Male hypopygium (Text-fig. I8) with posterior border of tergite, $t$, gently emarginate, lobes rounded, with very long setae. Dististyles, $d$, terminal, outer style a gently curved glabrous blade, apex broadly obtuse, slightly decurved ; inner style narrowed to the obtuse tip, provided with long yellow setae. Aedeagus, $a$, subequal in length to the longer gonapophyses, $g$, the latter twisted before the acute apex ; shorter apophysis a pale flattened blade, apex obtuse.

Holotype, ô, Tibet : Yatung, ro,ooo ft., ro.vi.rg28 (F. M. Bailey).

Other generally similar regional yellow species of the subgenus include Antocha (Antocha) basivena Alexander, A. (A.) khasiensis Alexander, A. (A.) perstudiosa Alexander, $A$. (A.) scelesta Alexander and $A$. (A.) studiosa Alexander, all differing among themselves in the coloration of the wings and femora and, especially, in the structure of the male hypopygium, including both dististyles, and phallosome. The species most similar to the present fly is basivena.

\section{Phyllolabis pallidivena sp. $\mathrm{n}$.}

General coloration of thorax light fulvous brown ; head dark grey ; antennae relatively long, basal flagellar segments elongate, testaceous yellow ; legs yellow ; wings light fulvous, cells $C$ and $S c$, with the stigma, slightly darker, veins yellow ; $R s$ about one-third longer than $R_{\mathbf{2 + 3 + 4}}$; abdomen obscure fulvous brown ; cerci slender, margins smooth.

Female. Length, about $6 \cdot 5-6.8 \mathrm{~mm}$.; wing, $7 \cdot 5-8 \cdot 3 \mathrm{~mm}$.

Rostrum and palpi brownish black. Antennae with scape brown, pedicel and proximal flagellar segments testaceous yellow, outer flagellar segments infuscated ; antennae long, basal flagellar segment lengthened, outer segments progressively smaller. Head dark grey ; anterior vertex about one and a half times the diameter of scape.

Pronotum brown. Mesonotal praescutum almost uniformly light fulvous brown, mid area faintly pruinose ; posterior sclerites of notum darker reddish brown; setae of notum sparse but long. Pleura dark reddish brown. Halteres with stem dirty white, knob infuscated. Legs with coxae light brown; trochanters yellow; remainder of legs yellow; claws very small. Wings (Text-fig. I3) light fulvous, cells $C$ and $S c$, with the stigma, very slightly darker ; veins yellow. Macrotrichia on longitudinal veins beyond level of origin of $R s$, including also all of $S c$, outer two-thirds of $M$, more than outer half of $C u_{1}$, and virtually all of both Anal veins. Venation : $R s$ about one-third longer than $R_{2+3+4}$. 
Abdomen obscure fulvous brown, including the genital segment, subterminal region slightly darker. Ovipositor with cerci slender, tips acute, margins smooth.

Holotype, ㅇ, N.E. Burma : Adung Valley, I2,000 ft., I6.viii.I93I (Kingdon-Ward \& Lord Cranbrook).

Paratopotype, ㅇ.

Among the regional members of the genus Phyllolabis pallidivena is most similar to $P$. beesoni Alexander, having the body coloration much the same, differing evidently in the wing coloration, especially the stigma and very pale wing veins.

\section{Limnophila (Prionolabis) kingdonwardi sp. $\mathrm{n}$.}

General coloration polished black ; antennae of male elongate ; femora yellow basally, tips broadly blackened, more extensively so on fore and middle legs ; wings moderately infuscated, cells $C$ and $S c$ and a cloud over the anterior cord darker ; cell $M_{1}$ present ; male hypopygium with outer dististyle shallowly bifid at apex ; inner style deeply divided into two long unequal arms.

Male. Length, about $8 \mathrm{~mm}$. ; wing, $8.3 \mathrm{~mm}$. ; antenna, about $2.8 \mathrm{~mm}$.

Female. Length, about $8.5 \mathrm{~mm}$. ; wing, $7 \cdot 2 \mathrm{~mm}$.

Rostrum and palpi black. Antennae dark brown, elongate in the male ; flagellar segments protuberant on lower face, dorsal surface with elongate verticils that exceed the segments, these smaller on outer segments ; verticils of lower protuberant face small, less than one-half the segment; a short dense white pubescence on all flagellar segments. Head dull blackish grey ; vestiture elongate, black, porrect.

Pronotum dark brown. Mesonotum polished dark brown or brownish black; vestiture of praescutal interspaces, scutum and scutellum very long, black, erect. Pleura brownish black, dorsopleural membrane dark brown. Halteres with stem whitened, knob weakly infuscated. Legs with coxae dark brown ; trochanters obscure yellow ; femora yellow basally, tips dark brown, more extensive on fore and middle pairs where about the outer two-thirds to threefourths are darkened, on hind femora less than the outer half ; tibiae and basitarsi brownish yellow, tips narrowly dark brown, outer tarsal segments passing into dark brown ; legs with long conspicuous setae. Wings (Text-fig. I6) moderately infuscated, restrictedly patterned with darker brown, including stigma, cells $C$ and $S c$ and narrow seams over anterior cord, prearcular field yellowed ; veins brown, yellowed in prearcular field. Longitudinal veins beyond cord chiefly with macrotrichia, lacking on $R_{2+3+4}$; before cord on outer third of $R s$, outer ends of $M$ and $C u$, and most of both Anal veins. Venation : $S c_{1}$ ending nearly opposite fork of $R s$, the latter elongate ; $R_{2+3+4}$ and basal section of $R_{5}$ subequal ; cell $M_{1}$ present, longer than its petiole ; $m-c u$ at or before midlength of $M_{3+4}$.

Abdomen, including hypopygium, black in male, more brownish black in female. Male hypopygium (Text-fig. I7) with the central area of posterior border of tergite, $t$, slightly produced ; tergite with long conspicuous setae. Basistyle, $b$, with long setae, including a compact group of very long bristles on mesal face near apex, the longest about as long as the outer dististyle. Outer dististyle, $d$, dilated at base, narrowed outwardly, apex shallowly and unequally bifid. Inner dististyle deeply divided, the inner arm shorter and more slender, outer arm fringed on inner margin with long erect setae. Phallosome, $p$, as figured ; basal plates enlarged; gonapophyses narrow, tips obtuse ; aedeagus long and slender but with an oval flange at near midlength, this separated from remainder of phallosome by hyaline membrane.

Holotype, ô, N.E. Burma : Adung Valley, 8,00o ft., I2.vi.I93I (Kingdon-Ward \& Lord Cranbrook).

Allotopotype, o, with the type, 9.vi.I93I.

This distinct fly is named after the late Frank Kingdon-Ward, outstanding botanist 
and plant collector, whose accounts of his expeditions in Manipur, northern Burma and southeastern Tibet have been of great value in an understanding of the Tipulidae that he captured. The only other regional member of the subgenus Prionolabis Osten Sacken having cell $M_{1}$ of the wings present is Limnophila (Prionolabis) filosula Alexander, of western China. The others, including L. (P.) carbonis Alexander, L. (P.) lictor Alexander and $L$. (P.) poliochroa Alexander, of western China, L. (P.) fletcheri Senior-White and some others still undescribed from the eastern Himalayas, lack this cell and all differ markedly in hypopygial structure. In the western Palaearctic fauna, $L$. (P.) longeantennata Strobl has cell $M_{1}$ present, $L$. (P.) cognata Lackschewitz and $L$. (P.) platyptera (Macquart) with the cell lacking, all with entirely different hypopygia.

\section{Cheilotrichia (Empeda) microdonta Alexander}

Cheilotrichia (Empeda) microdonta Alexander, 1957, Ann. Mag. Nat. Hist. (12) 10 : 295.

The type was from Mahthantir Gah, Kashmir, altitude II,ooo ft., taken August 9, I954 by Fernand Schmid. The present material greatly extends the known range. TibeT : Gyantse, I3,00o ft., 4.viii.I928 (F. M. Bailey).

\section{Ormosia (Ormosia) grahami Alexander}

Ormosia grahami Alexander, I931, Philippine Jour. Sci. $44: 364-365$, pl. I, fig. 20 (wing).

The type of this very distinct fly was from Szechwan, China, taken June 30, I929 by David C. Graham. It is known also from Sikkim, where it was secured at Chumzomoichoka, in the Rhododendron association, altitude II,800 ft., by Fernand Schmid, and from Kumaon, in the western Himalayas, taken at Kutara, Pauri Garhwal, altitude I2,000 ft., also by Schmid.

N.E. Burma : Adung Valley, I2,000 ft., Ir.viii.I93I (Kingdon-Ward \& Lord Cranbrook).

\section{REFERENCES}

Alexander, C. P. I95I. New or little-known Tipulidae (Diptera). XCI. OrientalAustralasian species. Ann. Mag. Nat. Hist. (I2) 4 : I072-I Io2.

1952. The same. XCIII. Oriental-Australasian species. Ibid., (I2) $5:$ I,090-I,III. I953a. The same. XCIV. Oriental-Australasian species. Ibid., (I 2) 6 : 174-I92.

I953a. The Oriental Tipulidae in the collection of the Indian Museum. Part III. Rec. Indian Mus. $50: 321-358$, I5 figs.

196r. The Himalayan species of the genus Phyllolabis Osten Sacken (Diptera : Tipulidae). Trans. R. Ent. Soc. Lond., 113 : I39-I 53, 21 figs.

I96ra. New or little-known Tipulidae from Eastern Asia (Diptera). XLIX. Philippine Jour. Sci. 90 : 155-214, 6 pls.

KaUlback, Ronald. I939. Salween, 33I pp., 3 maps, 23 pls. Harcourt, Brace and Company, New York.

WARD, F. KINGDON-. I934. A plant hunter in Tibet. 317 pp., 2 maps, 19 pls. Jonathan Cape, London.

_ 1937. Plant hunter's paradise. 347 pp., 2 maps, 13 pls. Jonathan Cape, London. 


\section{$2 \mathrm{BHL}$ Biodiversity Heritage Library}

Alexander, Charles P. 1963. "Some Tipulidae from Tibet and upper Burma in the British museum (natural history) (Diptera)." Bulletin of the British Museum (Natural History) Entomology 14, 319-340.

https://doi.org/10.5962/bhl.part.8785.

View This Item Online: https://www.biodiversitylibrary.org/item/19401

DOI: https://doi.org/10.5962/bhl.part.8785

Permalink: https://www.biodiversitylibrary.org/partpdf/8785

\section{Holding Institution}

Natural History Museum Library, London

\section{Sponsored by}

Natural History Museum Library, London

\section{Copyright \& Reuse}

Copyright Status: In copyright. Digitized with the permission of the rights holder.

Rights Holder: The Trustees of the Natural History Museum, London

License: http://creativecommons.org/licenses/by-nc-sa/4.0/

Rights: http://biodiversitylibrary.org/permissions

This document was created from content at the Biodiversity Heritage Library, the world's largest open access digital library for biodiversity literature and archives. Visit BHL at https://www.biodiversitylibrary.org. 